\title{
DEREGULATION, ECONOMIC GROWTH AND GROWTH ACCELERATION
}

\author{
Petar Stankov
}
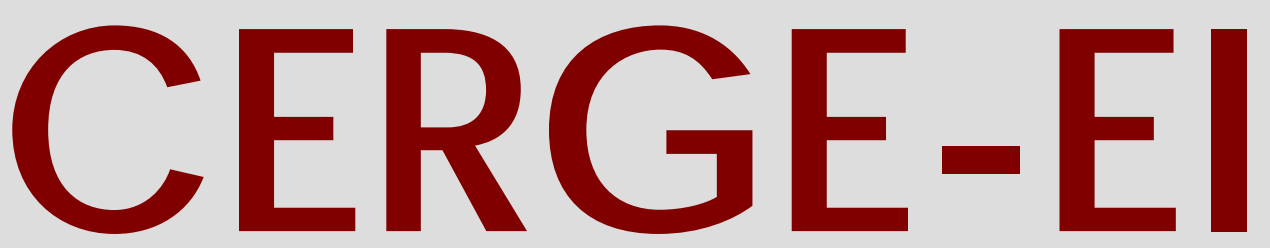

Charles University Centerfor Economic Research and Graduate Education Academy of Sciences of the Czech Republic Ec onomic s Institute 


\title{
Working Paper Series 44 (ISSN 1211-3298)
}

\section{Deregulation, Economic Growth and Growth Acceleration}

\author{
Petar Stankov
}

CERGE-EI

Prague, October 2010 
ISBN 978-80-7343-223-2 (Univerzita Karlova. Centrum pro ekonomický výzkum a doktorské studium)

ISBN 978-80-7344-213-2 (Národohospodářský ústav AV ČR, v.v.i.) 


\title{
Deregulation, Economic Growth and Growth Acceleration
}

\author{
Petar Stankov \\ CERGE-EI* and UNWE ${ }^{\ddagger}$
}

\begin{abstract}
The paper analyzes the influence of credit-, labor-, and product market deregulation policies on economic growth in more than 70 economies over a period of 30 years. It addresses both the issues of reform measurement and its endogeneity. Specifically, by combining a difference-in-difference strategy with an IV approach to the endogeneity of the reform timing, this work finds that deregulation contributed to the per capita GDP levels of the early reformers relatively more than to the ones of the late reformers. However, the paper also finds that accelerating credit market reforms leads to a large growth acceleration effect for the late reformers, which points to large dynamic welfare gains from deregulation. The latter result suggests that a large-scale credit market re-regulation in the aftermath of the Great Recession is a misguided approach to deal with the consequences of the financial crisis.
\end{abstract}

\begin{abstract}
Abstrakt
Tato studie analyzuje vliv politiky deregulace úvěrového, pracovního a produktového trhu na hospodářský růst ve více než 70 ekonomikách po dobu 30 let. Zabývá se jak otázkami měření dopadů reforem tak i jejich endogenními vlastnostmi. Konkrétně se tato studie zabývá tím, že kombinací rozdílových strategií s přristupem typu IV k endogenním vlastnostem načasování reforem se zjišt'uje, že deregulace přispěly $\mathrm{k}$ úrovním HDP dřívějších reformátorů relativně více než $\mathrm{k}$ těm reformátorů z pozdějších dob. Nicméně, tato studie také vedla ke zjištění, že urychlení reforem úvěrového trhu má za následek velké zrychlení růstu pro pozdější reformátory, což poukazuje na dynamický přínos v oblasti sociální péče a veřejného blaha zavedením výše zmíněné deregulace. Poslední výsledek naznačuje, že v době po Velké Recesi se velké přeregulování úvěrového trhu jeví jako chybný krok při řešení dopadů finanční krize.
\end{abstract}

Keywords: Deregulation; Economic Growth; Origins of Institutional Change JEL classification: N43, K20

${ }^{*}$ Center for Economic Research and Graduate Education-Economics Institute, a joint workplace of Charles University in Prague and the Academy of Sciences of the Czech Republic. Address: CERGE-EI, P.O. Box 882, Politickych veznu 7, Prague 1, 111 21, Czech Republic.

${ }^{\ddagger}$ Department of Economics, University of National and World Economy, J.K. Studentski Grad, 1700 Sofia, Bulgaria. All errors are mine. Comments are welcome at petar.stankov@cerge-ei.cz 


\section{Introduction}

After the first oil shock of 1973, the developed economies experienced a dramatic decline in their economic growth (Nordhaus, Houthakker, \& Sachs, 1980; Sachs, 1982) and labor productivity growth (Baily, Gordon, \& Solow, 1981). Since the mid-1970s, the productivity decline triggered a wide range of policy responses, including economic deregulation. ${ }^{1}$ Deregulation reforms were initiated in the US (Winston, 1998; Morgan, 2004), followed by the UK and other developed economies in the early 1980s (Pera, 1988; Healey, 1990; Matthews, Minford, Nickell, \& Helpman, 1987) and were imitated by the new democracies and many developing countries in the 1990s with an extensive set of labor-, capital-, and product-market reforms. The process continued throughout the early years of the $21^{\text {st }}$ century (Wölfl, Wanner, Kozluk, \& Nicoletti, 2009) until the recent global economic and financial crisis undermined the credibility of relaxing economic regulations.

The differences in the deregulation reform timing across countries point to a natural question: Did the early reformers - those countries reforming extensively in the 1970 s and the $1980 \mathrm{~s}$ - benefit more than the late reformers in terms of improving their living standards and in accelerating economic growth? If they did, then the economies that innovated with deregulation enjoyed growth, while those who imitated best-practice institutions did not always benefit from deregulation, as some evidence suggests (Rodrik, 2008). Answering this question is important at least for two additional reasons. On the one hand, a substantial bulk of the literature uses the time variation of various indices of regulation to gauge deregulation reforms. However, using those directly into a regression equation is problematic because equal changes in the indices represent unequal policy changes across countries. This work proposes a way out from this measurement problem by using the time variation of the reforms across countries to set up a difference-in-difference problem. On the other hand, few papers account for

\footnotetext{
${ }^{1}$ Following Winston (1993) the economic deregulation may be interpreted as the state's withdrawal of its legal powers to direct pricing, entry, and exit within an industry.
} 
where the time variation in the indices comes from in the first place, and if they do, their instruments are rarely time-varying. This paper constructs a new instrumental variable (IV) for deregulation reform that varies across countries and over time, which is arguably both strong and valid in predicting the timing of the deregulation reform. Specifically, the IV used here is the share of local consumption of total energy resources that can be satisfied with local production, or, in other words, the country's own energy independence. We find enough support for the hypothesis that the more energy independent the country is, the later it deregulates. Thus, the paper addresses simultaneously two of the long-standing problems in the empirical analysis of deregulation reforms. At the same time, the work supports the previous evidence of a positive impact of deregulation on growth.

The results also demonstrate important differences in the reform outcomes across countries. The benefits from deregulation were unequally spread, and the timing of the reform played an important role in reaping those benefits. Specifically, while early reformers enjoyed higher living standards, it is the late reformers' growth that accelerated most, especially after a credit market deregulation reform. Then, despite the evidence that most reforms do not produce growth accelerations (Hausmann, Pritchett, \& Rodrik, 2005), credit market reforms seem to be an exception. Therefore, they require special attention, especially when the need for faster recovery is coupled with a widespread political drive to re-regulate the financial sector.

The paper delivers two main messages. First, deregulation contributed to growth but its impact was different across countries, and the deregulation reform timing can at least partly explain the cross-country differences in the reform outcomes. Second, a large-scale financial re-regulation would backfire with substantial negative dynamic effects on growth acceleration, which may delay a strong recovery in the aftermath of the Great Recession. 


\section{Literature Review}

The theoretical political economy argumentation behind the large-scale deregulation reforms initiated in the late 1970s is two-fold. On the one hand, deregulation reduces the rents that regulation creates for workers, incumbent producers, and service providers. This view has gained a widespread popularity among academics and policymakers alike ever since the seminal works by Stigler (1971), Posner (1975), and Peltzman (1976) contributed to the understanding of the political economy of regulation. On the other hand, deregulation allows the newly created competition on the product-, labor- and capital markets to determine the winner of those rent transfers. Thus, by spurring productivity and efficiency gains (Winston, 1993), economic deregulation ultimately contributes to the overall increase in economic growth. The additional growth is brought primarily through increased employment and real wages (Blanchard \& Giavazzi, 2003), which affects both production and consumption and through increased investment (Alesina, Ardagna, Nicoletti, \& Schiantarelli, 2005), which affects the capital stock in the economy.

However, a more recent take on the efficiency gains from deregulation in the developing world provides a word of caution. The key contention in this newer line of literature is that deregulation reforms influence different economies differently, depending on their position on the technology ladder and on their quality of institutions. For example, Acemoglu, Aghion and Zilibotti (2006) claim that certain restrictions on competition may benefit the technologically backward countries, while Estache and Wren-Lewis (2009) find that the optimal regulatory policies in developed and in developing countries are different because of differences in the overall institutional quality in those countries. In addition, Aghion, Alesina and Trebbi (2007) use industry-level data to demonstrate that within each economy, institutional reforms influence different industries differently, and more specifically, industries closer to the technology frontier would be affected more by deregulation and would innovate more than the backward industries in order to 
prevent entry. As a result, countries closer to the technology frontier would benefit more from deregulation. The alleged benefits of economic deregulation in many industries prompted a debate on the growth effects from specific types of reforms, such as capital-, labor-, and product-market deregulation.

Although various authors interpret the scope of product market regulation (PMR) reforms differently, ${ }^{2}$ most agree that PMR reforms include deregulation of at least pricing and entry. As the literature on entry regulation suggests, stricter and more costly procedures to set up a firm are associated with lower GDP levels (Djankov, La Porta, Lopez-de-Silanes, and Shleifer, 2002). As it is the case with other empirical studies on deregulation reforms, it is tempting to interpret this finding as a policy recipe for growth because it implies that entry deregulation causes economic growth. Yet it is obvious that such an interpretation is superficial at least because to be able to derive growth effects of a given regulatory reform, one needs to focus on the effects of the changes in regulations over time rather than their levels. ${ }^{3}$

Despite its methodological modesty, the powerful novelty of the conclusions of Djankov et al. brings about many extensions. ${ }^{4}$ For example, by using firm-level data Scarpetta, Hemmings, Tressel and Woo (2002) find that PMR hampers both total factor productivity and entry in OECD countries, while Alesina, Ardagna, Nicoletti and Schiantarelli (2005) build upon those findings to emphasize a pos-

\footnotetext{
${ }^{2}$ For example, Wölfl, Wanner, Kozluk, \& Nicoletti (2009, p.11-12) include direct control of pricing behavior of private firms, administrative burdens on the setting up of a corporation and a sole proprietorship, barriers to trade and foreign investment, among other reforms; Gwartney and Lawson (2009, p.6) study price controls, start-up regulations, licensing restrictions, administrative requirements for businesses, bureaucracy costs and other business regulations; the World Bank Doing Business reports consider an extensive set of business regulations in ten different areas, including starting and closing a business; while Kaufmann, Kraay, and Mastruzzi (2009, p.6) aggregate data on the product market, the financial market, and the international trade and investment regulations from various underlying sources such as the Economist Intelligence Unit and the Heritage Foundation which capture the general "ability of the government to formulate and implement sound policies and regulations that permit and promote private sector development."

${ }^{3}$ Campos and Coricelli (2002) were among the first to suggest that reform changes rather than their levels might be more appropriate to include in an empirical analysis of the impact of institutions on growth.

${ }^{4}$ Djankov (2009) reports that 195 academic articles emerged as a result of this paper and the subsequent work of the Doing Business team at the World Bank.
} 
itive causal relationship between deregulation and investment in seven OECD industries. Further, Barseghyan (2008) supports the causal relationship with an IV estimation on a sample of between 50 to 95 countries.

However, there are papers that do not find enough evidence that institutional reforms, including deregulation, matter for economic performance. Commander and Svejnar (2007) use firm-level data from the Central and Eastern European countries and the former USSR to find that regulatory constraints do not affect firm performance. In addition, Babetskii and Campos (2007) conclude that the institutional impact on growth performance shows "remarkable variation" both in terms of sign and significance. A similar, if not even stronger, difference in opinion is found in the literature debates on the growth impact of labor- and credit-market regulation reforms.

Similarly to PMR, labor market regulations (LMR) also affect the growth factors. Yet, the literature on the effects of LMR on wages, working hours, and labor productivity is also not unanimous. For example, severance payments are found to have no effect on wages because firms make workers pre-pay them back through the labor contracts (Lazear, 1990; Leonardi and Pica, 2007). On the other hand, van der Wiel concludes that mandatory notice worker protection increases wages (Wiel, 2008).

The debate on how labor regulations affect labor productivity and employment is also inconclusive. For example, MacLeod and Nakavachara (2007) test that more stringent labor regulations reduce employee turnover and lead to a more productive employee-employer relationship for some types of occupation, especially the high-skilled ones. Acharya, Baghai-Wadji, and Subramanian (2009) find support for the hypothesis that stricter labor dismissal laws encourage innovation within firms, and therefore, could potentially promote labor productivity and economic growth. The intuition is that labor laws provide the high-skilled innovative staff with a certain degree of insurance in case of a short-term failure to innovate. 
These results contradict the traditional argument that labor regulations impose costs to firms and thus reduce labor force participation, employment (Botero, Djankov, La Porta, Lopez-de-Silanes, \& Shleifer, 2004), and investment as well as value added per worker (Cingano, Leonardi, Messina and Pica, 2009). Autor, Kerr, and Kugler (2007) present evidence that imposing employment protection laws increases employment but reduces productivity in the US. Further, Bassanini, Nunziata, and Venn (2009) extend the latter evidence of a reduction in labor productivity as a result of more worker-friendly labor laws for a sample of OECD countries. By analyzing firm-level data from Italy, Boeri and Garibaldi (2007) are in line with the traditional view on labor regulations summarized in Cingano et al. (2009) and find strong support for the conclusion that employment protection reduces productivity.

The long-run effects from labor regulations on economic growth are further analyzed in Deakin and Sarkar (2008). Their conclusions support the "indeterminacy hypothesis". That is, the effects from labor laws on growth would ultimately depend on context-specific factors, and therefore, finding any evidence supporting or confronting the notion that regulation hampers growth is, perhaps, always tentative and should be interpreted with caution.

The discussion above confirms whether labor market reforms have an impact on economic growth is inconclusive (Freeman, 2009). ${ }^{5}$ The same can be said for the reform impact of credit market regulation (CMR).

In an excellent review of the state of the debate, Demirguc-Kunt and Levine (2008) present the reasons why credit market deregulation may lead to growth. They claim that financial deregulation, such as equity market liberalization and

\footnotetext{
${ }^{5}$ In a separate line of literature, labor regulation has an inconclusive effect on income inequality. For example, Rosenbloom and Sundstrom (2009) argue that labor market institutions have a significant impact on the income distribution. They support the conclusions by Fortin and Lemieux (1997) who find that labor market reforms increase wage inequality in the US, and side with the cross-country evidence by Freeman (2007) who finds that more regulated labor markets exhibit lower income inequality. However, in a more recent take at the issue, Scheve and Stasavage (2009) disagree with this argument, presenting a time-series evidence encompassing most of the 20th century. They find that income inequality in 13 industrialized countries was shrinking even before the stringent labor market institutions like the centralized wage bargaining were introduced. Thus, they conclude, there is little support for the crosssectional evidence that labor market institutions like centralized wage bargaining influenced significantly the income distribution.
} 
allowing foreign bank competition, may spur growth by improving the allocation of capital and reducing its cost, thereby increasing overall efficiency. In a similar spirit, Bekaert, Harvey, and Lundblad (2005) find that liberalizing the equity market leads to a 1 percentage point increase in the annual economic growth, while Demirguc-Kunt, Laeven, and Levine (2004, p. 593) conclude that "tighter regulations on bank entry and bank activities boost the cost of financial intermediation," which ultimately hampers growth.

The positive association between banking liberalization and economic growth is also found in earlier studies. ${ }^{6}$ Levine $(1998$, p.598) uses the legal origin as an instrumental variable for banking development on cross-country data to arrive at a "statistically significant and economically large relationship between the exogenous component of banking development and the rate of economic growth." Earlier, Jayaratne and Strahan (1996) apply a difference-in-difference strategy on US data to find that both output and per capita income rise after the relaxation of the intra-state bank branching restrictions.

Despite the positive growth implications from CMR reforms, both financial deregulation, which leads to innovations in the financial sector, and the lack of appropriate financial supervision are implied in the literature as some of the reasons behind the world financial and economic crisis of 2008-2009. For example, Gorton (2008) identifies the innovations in the financial industry as standing at the heart of the sub-prime crisis of 2007-2008. Furthermore, Diamond and Rajan (2009) claim that the US financial sector mis-allocated resources to the real estate sector by issuing new financial instruments. Therefore, without further investigation, which this work does, it would still be perhaps premature to claim that overall deregulation reforms cause economic growth.

This work extends the deregulation literature in two ways. First, it approaches the measurement of various deregulation reforms in a similar fashion to Estevadeordal and Taylor (2008) who transform the traditionally used reform indices into dummy variables in a way allowing for a difference-in-difference estimation. The

\footnotetext{
${ }^{6}$ See Levine (2005a) for an extensive review.
} 
advantage of this approach lies in using the reform indices to construct treatment and control groups rather than using the indices directly to infer the effect of a unit change of a reform index. Although widespread in the empirical literature, the direct use of the reform indices is rather uninformative of the true effect of a reform. Further, although it indicates the direction of the impact, it does not allow for meaningful comparisons of the effects across countries, as equal changes in the index represent unequal policy changes.

Second, and perhaps even more importantly than dealing with the measurement issue, few empirical papers clarifying the impact of deregulation on growth account for where the time variation in the indices comes from for such a broad range of countries like the ones in our sample. For example, Alesina et al. (2005) use lagged values of PMR indices as instruments for current regulation for OECD countries only. Further, they study the impact of the reform timing without taking into account the origin of the reform process. Barseghyan (2008) uses a number of instruments for entry regulations and property rights, such as geographical latitude, legal origins, settler mortality, and indigenous population density as early as the 16th century for a large sample of countries. However, as Barseghyan's instruments do not vary over time, they can explain only crosssectional variation in the reform data. As a result, the studies using those instruments fail to explain the time variation in deregulation reforms.

In contrast, we explore energy dependence across countries which also varies over time to predict the timing of the deregulation reforms, and only then study the impact of those reforms on growth. Beck and Laeven (2006) apply similar logic to a broad aggregate index of institutional reforms in 24 transition economies. However, their work does not utilize the time variation of natural resource dependence, which means the selection into the timing of reforms remains as elusive as before. Further, their work uses directly indices of institutional reforms. 


\section{Empirical Strategy}

The literature review points to two methodological issues that need to be addressed in the analysis of any institutional impact on growth: the measurement of reforms and the endogeneity of the reform timing. In this section, we present one possible approach to deal with both at the same time in the context of deregulation. The benchmark model addresses primarily the measurement issue, while the 2SLS model builds upon it while approaching the endogeneity issue.

\subsection{Benchmark model}

Much in the spirit of Estevadeordal and Taylor (2008), we define reformers between 1975 and 1990 as countries with an above-median (above-mean) increase in the Economic Freedom of the World (EFW) index of regulation between 1975 and 1990 and non-reformers otherwise. Identically, reformers between 1990 and 2005 are defined as countries with an above-median (above-mean) increase in the EFW index of regulation between 1990 and 2005 and non-reformers otherwise. Thus, four distinct groups of countries emerge: 1) non-reformers in the first period becoming reformers in the second period (late reformers); 2) reformers in the first period becoming non-reformers in the second period (early reformers); 3) reformers in both periods ("marathon" or persistent reformers); and 4) nonreformers in both periods. The first three groups are the policy treatment groups in all baseline estimations, while non-reformers are the control group.

Although the data split may seem a bit arbitrary, it is justified for several reasons. First, the data are such that they allow for two equally long periods to be constructed in both deregulation reforms and growth performance. Second, 1990 marks an important change in economic history with the start of many market-oriented reforms across a wide range of economies. As the data description demonstrates, the reforms before 1990 were rather sporadic and with a small variance across countries over their magnitude, while after 1990 they were widespread but varying in their magnitude, which presents a suitable opportu- 
nity for a difference-in-difference study. Third, splitting the data into smaller periods would undermine capturing some effects that materialize over longer periods of time within each economy; it would also present a challenge in capturing a policy variation in deregulation within a decade or within a shorter span, as many economies might not reform at all within shorter periods of time. Finally, the 1990 threshold is not new to the literature on the impact of deregulation on growth: Alesina et al. (2005) use it as well. Therefore, we consider splitting the data into two relatively long 15 -year periods suitable for this empirical work.

To answer our main question, we estimate the following benchmark equation:

$$
\Delta y_{i t}=\beta_{1}+\beta_{2} \mathrm{ER}_{i t}+\beta_{3} \mathrm{LR}_{i t}+\beta_{4} \mathrm{MR}_{i t}+\beta_{5} X_{i t}+\Delta \varepsilon_{i t},
$$

where $\Delta y_{i t}$ is either the difference in the average log-GDP per capita for country $i$ in period $t, \Delta \operatorname{Avg} \cdot \log (G D P)_{i t}$, to measure the one-time level effect from the reform, or the difference in the compound growth rates between the two periods, denoted by $\Delta g_{i t}$, to measure the acceleration effect $;^{7} E R_{i t}$ is a dummy variable equal to 1 if the country was an early reformer and to 0 otherwise; $L R_{i t}$ is a dummy variable equal to 1 for the late reformers and to 0 otherwise; $M R_{i t}$ are the countries that were reformers in both periods; $X_{i t}$ is a vector of country characteristics, such as the initial level of GDP in 1975 to control for growth convergence and initial conditions, and other institutional reform covariates such as barriers to trade; and $\Delta \varepsilon_{i t}$ is an error term about which we assume, at least for now, that the standard linear regression assumptions are satisfied. Finally, note that with only two reform periods - before and after 1990 - the $t$-dimension collapses to 1, which effectively means performing a cross-sectional estimation on differenced data.

\footnotetext{
${ }^{7}$ The compound growth rate for country $i$ within each 15 -year period $t$ is measured as $g_{i t}=\left[\left(x_{n} / x_{0}\right)^{1 / 15}-1\right]^{*} 100$, where $x_{0}$ is the initial level of per capita real GDP, while $x_{n}$ is the terminal level. Thus, the compound growth rate measures the growth rate of the economy as if it was growing with the same rate throughout the period. We do not use the least squares growth rate because its estimation requires a sufficiently large number of observations over time.
} 


\subsection{SLS estimation}

The above benchmark estimation does not account for the selection process into the various treatment and control groups. To do that, the following local average treatment effect (LATE) model is estimated as a first-stage of a 2SLS procedure: ${ }^{8}$

$$
\Delta y_{i t}=X_{i t}^{\prime} \beta+\alpha D_{i t}+v_{i}
$$

where $X^{\prime}{ }_{i t}$ is the vector of the observed explanatory variables described above, and $D_{i t}$ is the treatment indicator that depends on the instrumental variable, $z_{i t}$, in a way that $D^{*}{ }_{i t}=\gamma_{0}+\gamma_{1} z_{i t}+u_{i}$ is a latent variable with its observable counterpart $D_{i t}$ generated by:

$$
D_{i t}= \begin{cases}0 & \text { if } D^{*}{ }_{i t} \leq 0 \\ 1 & \text { if } D^{*}{ }_{i t}>0\end{cases}
$$

Equation (3) means that the reform participation equation $D_{i t}$ is driven by some unobservable factors $D^{*}$ it that in turn depend on some predetermined country characteristics $z_{i t}$ which we assume exogenous. Those characteristics are the instrumental variables which vary over time and can arguably predict the selection into early, late, and marathon reformers. The instrument, $z_{i t}$, is the dependence on energy resources of a country $i$ in period $t$. In line with the political economy literature, we argue that the more energy abundant the country is, the less incentives its policy makers have to deregulate at any point in time, and therefore, the more energy abundant the country is, the probability of reforming early declines. At the same time, however, changes in the resource dependence may also influence political decisions to reform or to revert reforms at any point in time. Therefore, the instrument is constructed as follows:

$$
z_{i t}=\frac{P_{i t}-C_{i t}}{C_{i t}}, z_{i t} \in[-1 ; \infty)
$$

\footnotetext{
${ }^{8}$ The model is detailed in Cameron and Trivedi (2005, pp.883-884).
} 


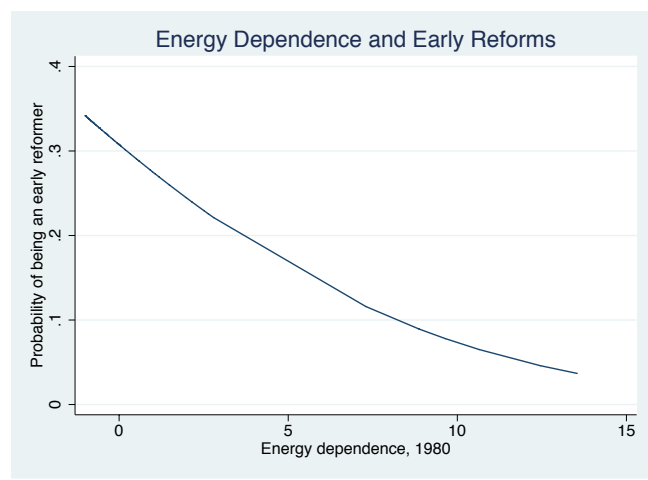

(a)

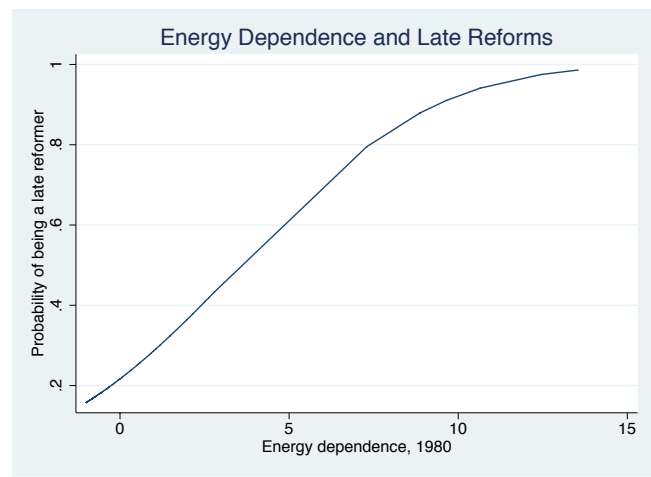

(b)

Figure 1: The probability of early/late treatment and energy dependence

where $P_{i t}$ is the production, and $C_{i t}$ is the consumption of energy in a given year between 1980 and 2004, where the time variation in the energy dependence is also exploited to predict the reform timing. ${ }^{9}$ The variable $z_{i t}$ also means that the more production of energy there is in the country, the more energy-independent the country becomes. For example, if $z_{i t}=9$, then the country produces 10 times more energy than it consumes. ${ }^{10}$

The relationship between the energy dependence in 1980 - the first available year for $z_{i t}$ - and the probability of being an early/late reformer is presented in Figure 1. In line with our political economy expectations, panel 1(a) indicates that the more energy-independent the country is, i.e. the higher the share of its consumption which could be satisfied from local production, the lower the probability is of the country being an early reformer. In addition, panel 1(b) demonstrates that the energy-rich countries actually have a higher probability of reforming late.

The natural resource underpinning of institutional reforms is supported also by other empirical findings. For example, Levine (2005b) finds sufficient credibility in the idea that endowments create elites who subsequently form the property

\footnotetext{
${ }^{9}$ Effectively, this means we have a data point for $y_{i}$ and the timing of the reform $\left(E R_{i}, L R_{i}\right.$ or $M R_{i}$ ) and 25 possible instruments.

${ }^{10}$ As it includes diverse sub-indicators as petroleum, natural gas, coal, hydroelectric power, nuclear electric power, solar, wind, and waste electric power, the energy-dependence indicator is measured in the generic British Thermal Units (BTU).
} 
rights of a country in favor of themselves or in favor of a strong private sector. Further, Beck and Laeven (2006) isolate the exogenous component of the institutional variation by using the natural resource argument in the context of transition economies only to study the institutional impact on economic growth. We would extend their results to both developing and developed countries using the same argument.

Despite the extension in the scope of analysis, there is one major concern when using the time variation in energy dependence as an instrument for the timing of reforms: its correlation with living standards and growth. It is certainly true that energy consumption is correlated with both GDP levels and growth within a period. Higher GDP and GDP growth means higher energy consumption, and therefore higher energy dependence. At the same time, higher energy dependence leads to earlier and more consistent reform which makes richer and faster growing countries natural candidates for being early and marathon reformers. This should surface as positive biases in the 2SLS estimations with respect to the OLS estimations. $^{11}$

However, notice that both the reform variables and the dependent variables capture 15-year periods, while the instruments are annual observations of energy dependence. Thus, although certainly possible, any contemporaneous correlation between the instrument and the dependent variable is limited within a small segment of the reform timeline. Therefore, the possible biases resulting from those correlations should not affect significantly the main results. At the same time, the validity of the instrument is justified by the emerging evidence that energy dependence has only a short-term direct impact on economic growth, if it has any impact at all (Alexeev \& Conrad, 2009a, 2009b; and Aliyev, 2009), which justifies using this instrument over longer periods. Otherwise, applying it as an IV for reforms would not be a valid empirical approach.

\footnotetext{
${ }^{11}$ The results demonstrate that to a certain extent this argument holds ground.
} 


\subsection{Data}

\subsubsection{Deregulation reforms}

The explanatory variables on the changes of the index of regulation and other reforms are taken from the Gwartney and Lawson (2009) index of Economic Freedom of the World (EFW) data, which traces the economic policy development in 141 countries back to 1970 in the following relevant policy areas: 1) Size of Government: Expenditures, Taxes, and Enterprises; 2) Legal Structure and Security of Property Rights; 3) Freedom to Trade Internationally; and 4) Regulation of Credit, Labor, and Business. Those indices are transformed into reform variables, as outlined in the empirical model description. ${ }^{12}$ The main explanatory variable is taken from the changes in the index of Regulation of Credit, Labor, and Business.

\subsubsection{Country-level economic growth}

Perhaps the most comprehensive source of long-term economic growth data computed from the national accounts of 188 countries is the Penn World Table (PWT). That is why we use the PWT 6.3. ${ }^{13}$ for the dependent variable in the initial estimations of equation (1). Our main dependent variables are the GDP per capita and the GDP per worker which are the RGDPCH and the RGDPWOK variables in the PWT. For every country in our sample, we construct the dependent variables as follows: We take the average log-level of GDP per capita for the first period (1975-1989) and difference it from the log-level of GDP per capita for the second period (1990-2004). As a result, for every country, we have a data point indicating the difference in average log-GDP between the two periods.

Further, within each 15-year period, and for each country, we construct a measure of the compound growth rate. We then difference the within-period ge-

\footnotetext{
${ }^{12}$ For a further detailed description of the EFW data, see Gwartney and Lawson (2009), p.6-9.

${ }^{13}$ Heston A., Summers R., \& Aten B. (2009). Penn World Table Version 6.3, Center for International Comparisons of Production, Income and Prices at the University of Pennsylvania, August 2009.
} 
ometrically averaged growth rates from each other to get the growth acceleration after 1990 - our second dependent variable. We have a match between the PWT growth rates and the EFW index of regulation in 71 countries, which is the final size of the sample.

As a supplementary dataset on growth performance and its factors, we use the World Bank Development Indicators database, which is arguably at least as precise as the PWT in its ability to measure economic growth and its factors in a large panel of countries. As there are some differences across datasets in the way the growth series are constructed, which might affect the results of the empirical estimations, ${ }^{14}$ using both datasets allows for a robustness check of the results.

Finally, the data on the energy production and consumption, which are needed to construct the novel energy dependence indicator, are taken from the Energy Information Administration (EIA) of the US government. The database contains annual observations for 148 countries between 1980 and 2004, the majority of which are also present in the Penn World Tables (PWT).

\subsubsection{Deregulation and economic growth trends since $\mathbf{1 9 7 5}$}

This section illustrates graphically how the deregulation policies developed from 1975 to 2005. The fairly long period of conducting those policies avoids the risk of having almost no policy change within a shorter span.

Figure 2(a) relates the index of overall regulation in 1975 with the same index 15 years later, and Figure 2(b) characterizes the relation for the period that followed. A variation in the data in both directions is observed for both periods. In the first period, most of the countries stand below the 45-degree line which means they made their regulations tougher between 1975 and 1990. However, in the second period, most of the countries stand above the 45-degree line which indicates improvement over their 1990 standpoint. ${ }^{15}$

\footnotetext{
${ }^{14}$ See, for example, Hanousek, Hajkova, \& Filer (2008) for a study of how the choice of data might affect the results of cross-country growth regressions.

${ }^{15}$ Note that a higher index of regulation in the data means less restrictive regulations.
} 


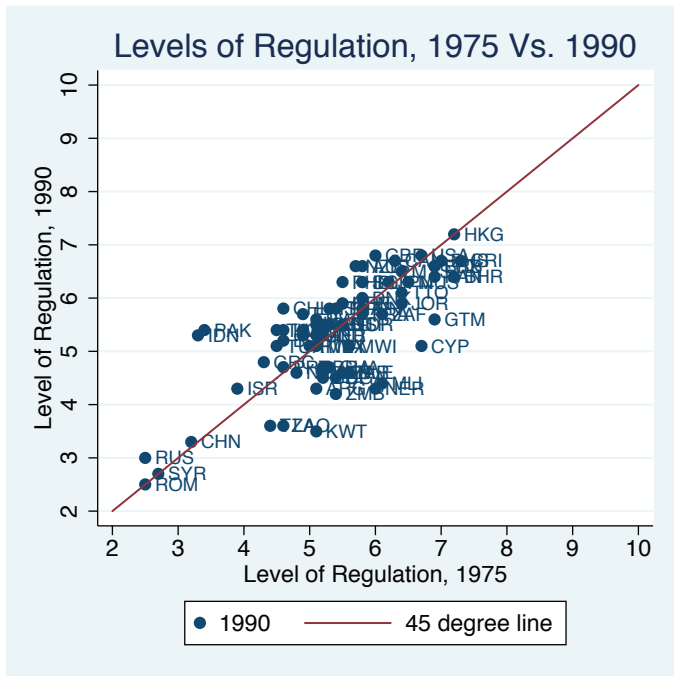

(a)

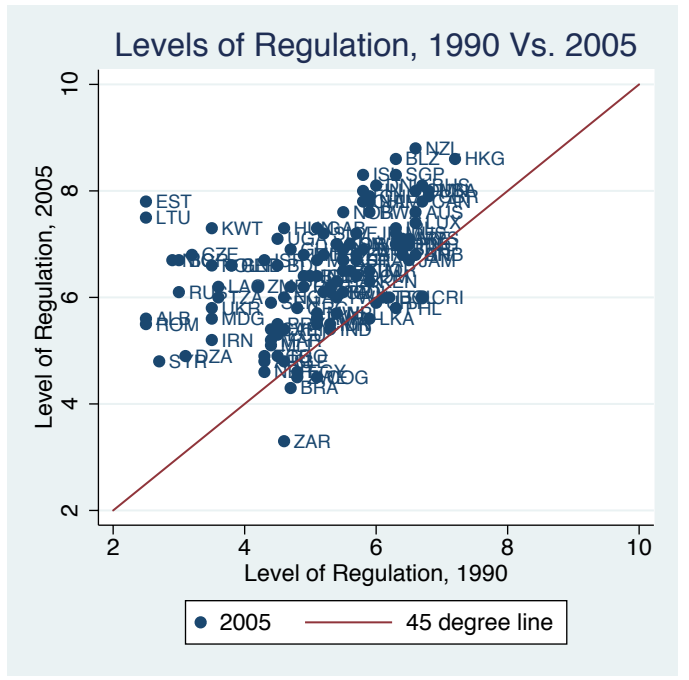

(b)

Figure 2: Overall Deregulation within Each Period

Although informative of the initial and the terminal states of regulatory environment, the figures above do not yield a sufficient representation of how the reform was moving between the two periods. These changes are presented more explicitly in Figure 3(a) where the relative change in the second period can be observed. The figure demonstrates that there was indeed a far more explicit consensus across countries as to the direction of policy change in the 1990s: Most of the countries embarked on a way towards deregulation.

The overall positive trend in deregulation, which is demonstrated by the increase in the indexes, is also clearly demonstrated in Figure 3(b) where the shift in the distribution of deregulation policies can be observed. Clearly, there is a marked difference before and after 1990 as to where the policy was going. Not only the majority of countries improved their regulatory environment, which is visible from the shift of the distribution to the right, but also far more countries were adopting more radical reforms to deregulate, which is obvious from the increased variance of the distribution. The results presented in the next section and in the robustness checks demonstrate that, indeed, the reform process brought benefits while stalling it did not add anything to living standards or to growth acceleration. 


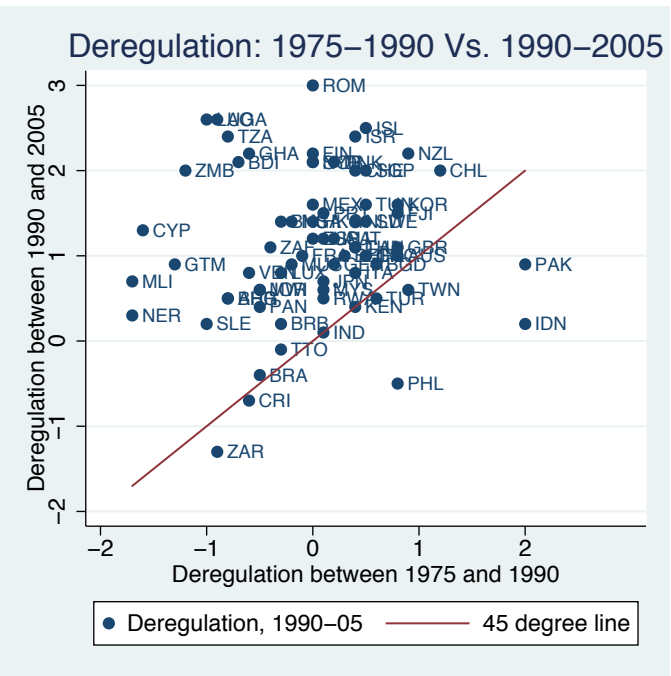

(a)

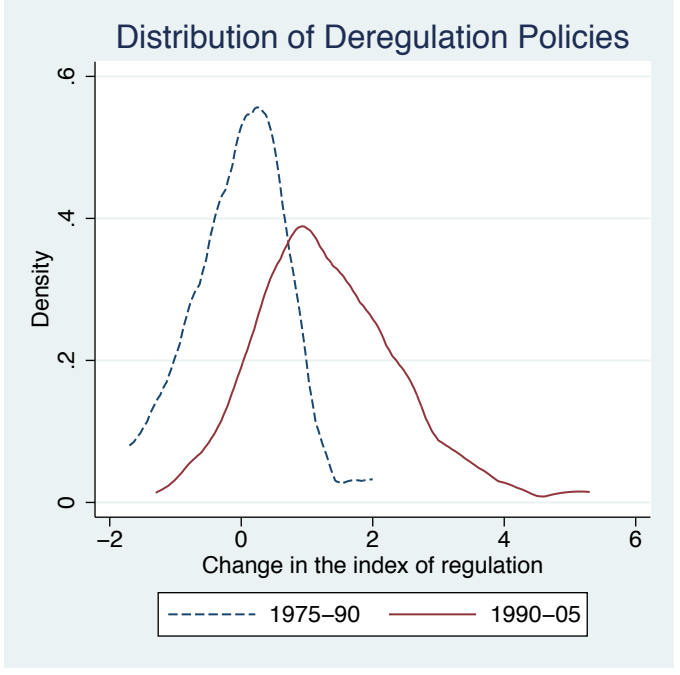

(b)

Figure 3: Overall Deregulation between Each Period

\section{Results}

The results from OLS and 2SLS estimations of the benchmark equation (1) in which the reform dummies are predetermined by the country's own energy dependence are presented in Table 1 . The table is divided into two main sections, identifying the two main discrimination criteria between reformers and non-reformers: the median and the mean criterion. In the first four models, the median criterion is being used, while the mean criterion is applied in the latter four models. This is done mainly for a robustness check rather than to find some new evidence beyond what we are after. Within each criterion, four estimations are carried out, two for each level of aggregation of the reform variable. In the first two models, OLS and 2SLS estimations are presented with the underlying explanatory variable being the overall index of regulation for the given economy. In the second pair of models, the underlying explanatory variable is the sub-index of regulation on the capital markets only. 
Table 1 demonstrates clearly that late deregulation reformers (LR), or those countries that lagged behind in their deregulation reform in the late 1970s and in the 1980s but accelerated the reform in the 1990s and in the early years of the $21^{\text {st }}$ century, had lower per capita GDP levels than the early reformers (ER) and those countries that reformed extensively in both periods - the "marathon" reformers (MR). Model (1) in Table 1 produces a statistically significant difference of slightly below $30 \%$ points of increase in the average $\log (G D P / c$.) for the entire period between the ERs and MRs on the one hand and the LRs on the other. This means deregulating early and continuously is also associated with higher living standards. The result is obtained when controlling for other institutional variables, such as removing trade barriers, and for initial GDP levels.

Controlling for the same variables in Model (2), at the same time estimating the model by 2SLS with energy dependence in each year between 1980 and 2005 as instrument for switching between reformers and non-reformers, the results not only retain their sign but also increase both their magnitude and their significance. This suggests the early and marathon reformers also become considerably richer in the course of the reform. At the same time, the instruments pass the Hansen over-identification restriction J-test, which is a good signal about their validity and strength.

However, even if they are valid and strong enough, the instruments are pointing to the effect of an overall deregulation reform. Thus, the above results are somewhat loose and difficult to interpret.

In models (3) and (4), we replace the explanatory overall reform variable with an identically constructed variable tracking down only one of the three reforms constituting the overall reform: the deregulation on the credit market. We do so because the variation in the overall reform variable admittedly captures a wide range of reforms simultaneously thereby limiting the chances for formulating specific deregulation policy implications. Although the results are not as strong as before in terms of magnitude, the sign remains indicative of the inherent difference between early and late reformers: The levels of per capita GDP of the early and 
marathon reformers were significantly higher than those of the late reformers. The same result holds when we instrument for the reform endogeneity, while the magnitude and the significance increases, as was the case with the benchmark 2SLS model (2).

The results above do not change even if we apply a different criterion for defining the reformers and non-reformers within each 15-year period. Using the mean instead of the median criterion, the early and the marathon reformers still appear better-off than both the late reformers and the non-reformers. The results indicate that our approach is robust to a reasonable but admittedly arbitrary definition of reformers.

Using the compound GDP/c. growth as the explained variable brings additional information on the growth effect from the deregulation reforms since 1975. Table 2 presents the results obtained from the compound GDP/c. growth regressions.

While in the previous estimations it was evident that the one-shot growth effect was different for the various types of reformers, the effect on growth acceleration is far less obvious. There is no significant difference between the various types of reformers in models (1) and (2), which indicates that an overall reform may not cause growth acceleration.

However, there appears to be a large positive and significant acceleration effect from the credit market deregulation alone but only for the late reformers. In models (3) and (4), we observe that the growth rates of the late reformers accelerate by about 1.61-3.42 percentage points per year after 1990, which is economically large and a statistically significant difference, the second one being significant at the $1 \%$ level. Just like before with the difference in log-levels of per capita GDP, the results appear stronger when estimated by the 2SLS method. The results here remain roughly the same when applying the mean criterion in models (5) to (8).

At first glance, two of the results seem hard to reconcile. First, why do the overall early and marathon reformers have higher living standards but insignif- 
icantly higher growth acceleration? After all, the higher living standards have to come from a growth process. Second, why do late CMR reformers have lower GDP levels but higher growth acceleration? When reconciling the finding that there is a significant level effect from the overall deregulation reform without an apparent acceleration effect, we have to bear in mind that all the results are relative to the non-reformers. The fact that there is no overall acceleration effect means that the ERs and MRs are growing with similar rates as the non-reformers. However, growing with $2 \%$ from a base of 100 produces a different level effect than growing with $2 \%$ from a base of 50 . Therefore, indeed ERs and MRs have become relatively richer than before, while growing at the same rate as the non-reformers. This shows up as a significant level effect without a significant growth acceleration effect. Similar logic applies to the second result. The LRs were poorer in the first period, while in the second they grew much faster than the rest. Thus, it appears that a large catch up process exists for those economies that reformed extensively in the 1990s. This can lead to dramatic differences in GDP per capita levels, when we take into account the long-term dynamic gains from such a large annual margin in favor of the late reformers.

The results here hold when testing with the other dependent variable - the GDP per worker. Thus, they do not add to our understanding of the main question and are therefore not presented here but are available upon request. The results from another set of robustness checks are presented in the next section.

\section{Robustness Checks}

\subsection{A classic difference-in-difference strategy}

The identification strategy in this work does not apply the classic difference-indifference framework. Instead, the paper uses a larger variation in the reform data and analyzes a richer pattern of reforms than a simple diff-in-diff would allow. However, this strategy also means that instead of having a comparison 
between two ex-ante similar groups, one of which switches to being a reformer (or a non-reformer), we group all countries together, and then compare them to the all-time non-reformers, at the same time accounting for where the initial differences come from. Although this approach has its merits, we have to treat the parameter estimates of the different groups of countries with some caution because we can no longer implicitly assume the countries in the sample ex-ante identical. Therefore, to solve this issue, we apply the first set of robustness checks.

Specifically, we conduct two standard sets of estimations for which we can justify the assumption of ex-ante similarity. In the first one, we take the initial non-reformers, and estimate the effect of switching to a reformer status in the second period. That is, in our original taxonomy, we compare the non-reformers with the late reformers for both the level and the growth acceleration effects. In the second set of estimations, we compare the early reformers with the marathon reformers and test if a reform backlash has a negative level and growth acceleration effect.

The results from these estimations are presented in Table 3 and Table 4, respectively. As we can see from columns (1) and (2) on Panel A of Table 3, an overall deregulation reform makes sense because it boosts the per capita GDP for those who reformed. However, it does not bring significant growth acceleration effects, as seen from the same columns on Panel B estimations, which is a robust result with the ones obtained before. Looking at credit market regulation policies alone, we find some less robust results with respect to the level effect: Late reformers lag significantly behind the non-reformers in the original estimations presented in Table 1, while the effect in Table 3 appears insignificant. Yet, the effect is quite robust with respect to the growth acceleration effects presented on Panel B of Table 3, where the same signs and significance levels and similar magnitudes are obtained with respect to Table 2 . Therefore, the most robust result from these estimations is that reforming the credit markets brings an additional 2-3 percentage points of annual economic growth to the countries that reformed after 1990 over and above the growth that the non-reformers experienced through the same period. 
If deregulating credit markets brings additional growth, then does credit market re-regulation reform make sense for boosting GDP levels and growth? This question is answered in Table 4, where we compare the countries who reformed in both periods with the countries who lagged behind in their overall and credit market deregulation in the second period. Neither of the effects appear significant at the $5 \%$ level, which points to the conclusion that a deregulation reform reversal, including the one on the financial markets, does not add anything to GDP and does not accelerate growth. This conclusion seems robust across all estimations.

\subsection{Using the PWT 6.2 and the World Development Indi- cators data instead of the newer PWT 6.3}

One of the criticisms aimed at the different versions of the PWT dataset is that they lead to a systematic variability of the levels and the growth estimates. ${ }^{16} \mathrm{In}$ turn, this problem might influence the results of our original estimations. We find that, indeed, there is a very small change in the magnitude of the estimated effects when using the PWT 6.2 instead of 6.3. Further, in some cases, the significance levels are shifted up or down a notch. Those changes however are not systematic and are consistent with the original conclusions.

The estimations run through the WDI dataset again do not lead to systematically different results from the ones obtained from the PWT 6.3 dataset. As before, reforming early and reforming throughout the two periods leads to a significant increase in living standards of about a percentage point per year, although the parameter estimates are a bit smaller than the ones obtained with the PWT 6.3 dataset. The estimations on the specific credit market regulation reform leads to identical conclusions. This is valid with both the median and the mean criterion for discrimination between reformers and non-reformers.

\footnotetext{
${ }^{16}$ See for example, Johnson, Larson, Papageorgiou and Subramanian (2009) about the PWT differences and Hanousek et.al. (2008) about the differences stemming from using different sources such as PWT and the World Development Indicators (WDI).
} 
The results are also robust when it comes to growth acceleration. Overall, neither using the PWT 6.2 nor the WDI datasets leads to significant differences to the ones obtained originally on the PWT 6.3 dataset. We find this an encouraging signal for a robust relationship between deregulation, levels of per capita GDP, and growth acceleration.

\subsection{Adding additional controls and instruments}

Due to the fact that there are quite different countries in our sample, we would like to know whether some relevant variables are being omitted. For example, are the OECD countries different from the rest in reacting to deregulation reforms; or, does the severe recession experienced by the transition countries after 1990 and the dramatic increase in their GDP growth thereafter bias the results? To answer those questions, we first add an OECD dummy in all estimations and find that it is insignificant. ${ }^{17}$

The transition country bias is also hardly possible in our estimations due to data considerations. The only former transition country with observations spanning across both GDP levels and growth, and deregulation patterns since 1975 in our sample is Romania. However, Romania does not have observations in the Freedom to trade internationally domain before 1990, which also means it is being automatically excluded from the estimations because the additional controls are missing. Therefore, the presence of transition countries in the sample changes nothing in the estimations.

The estimations are also robust to adding another instrument: the depth of the Great Depression. The logic behind this instrument is developed in the context of international trade by Estevadeordal and Taylor (2008). Applied in the context of regulations, we can argue that the countries that experienced a deeper depression during the 1930s also invoked a more pronounced government

\footnotetext{
${ }^{17}$ The OECD dummy takes into account the existing members of the Organization in 2010.
} 
intervention during the Depression and shortly thereafter. After WWII, this role became a tradition and was retained at least until the wave of deregulation reforms starting in the late 1970s. Therefore, those countries with a deeper Depression were more likely to have had more stringent regulations. Therefore, the countries that experienced a deeper Great Depression are also less likely to deregulate sooner, and be early or marathon reformers, including in trade policies. The depth of the depression instrument is actually the percentage point difference between the initial GDP in 1929 and the lowest GDP between 1929 and 1937.

The results from adding the depth of the Great Depression are again relatively robust to the original ones, at the expense of losing half of the observations because of a lack of data points in the Maddison dataset, which is used to construct the additional instrument. Again, reforming early and throughout the two periods makes the economies richer although the effects lose some of the previous magnitudes. This is true for both the overall reform and for the credit market reform and is retained after applying both the median and the mean criteria. When it comes to the growth acceleration effect, we find again that early and marathon reformers are losing the growth race: non-reformers and late reformers are growing faster in the second period even after controlling for initial income. Again, however, these results should be approached with caution, as the sample size varies between 34 and 40 countries. Still, it is encouraging that the results are robust to adding new instruments.

The results from the three broad sets of robustness checks here demonstrate that there is indeed a robust positive relationship between being early and a marathon reformer and the levels of per capita GDP. In addition, reforming credit markets late is associated with lower levels of per capita GDP but with a faster catch up process emanated in a significant growth acceleration effect for the late reformers. The results in this section are sufficient to conclude this work about the causal effect of deregulation on economic growth. 


\section{Conclusion}

The effects from deregulation on living standards and on growth vary across economies and across the timing of the deregulation reform. The countries that lagged behind in their deregulation reform in the late 1970s and in the 1980s but accelerated the reform in the 1990s and early in the new century had lower per capita GDP levels than the early reformers and those countries that reformed extensively in both periods - the "marathon" reformers. This means deregulating early and continuously is also associated with higher living standards. However, when it comes to growth acceleration, there is no significant difference between the various types of overall deregulation reformers. This result suggests that an overall reform does not necessarily cause growth acceleration.

In order to analyze the impact of a more specific reform, we consider the impact of deregulation on the credit markets alone. Although the results are not as strong as before in terms of magnitude, the sign remains indicative of the inherent difference between the early and the late reformers: late credit market deregulation is also associated with being poorer.

However, there appears to be a large positive and significant growth acceleration effect from the credit market deregulation for the late reformers. Depending on the estimations, the late reformers' permanent advantage over non-reformers varies between 1.6 and 3.6 percentage points of annual economic growth. This can lead to dramatic differences in per capita GDP levels over longer periods of time when taking into account the long-term dynamic gains from such a large growth margin in favor of the late reformers. The main message from this result is that it is better to reform late than never as it seems there forms a certain catch up process in the countries lagging behind their deregulation policies but accelerating the reform later on. This result also suggests that there could be large dynamic welfare losses if credit market deregulation reforms lose momentum against the backdrop of the global financial and economic crisis of 2008-2010. 
This conclusion is also supported by the robustness checks in which we split the countries into two groups, which are ex-ante very similar, and are ready for a classic difference-in-difference estimatien. We conclude that a deregulation reform reversal, including the one on the financial markets, does not add anything to GDP and does not accelerate growth. This conclusion seems robust across all estimations. The results appear robust not only to a modification in the estimation strategy but also to adding new control variables, adding new instruments, using different datasets, and to dropping observations we suspect to cause biases.

This work leaves additional unanswered questions. First of all, how do the other regulatory reforms affect growth and growth acceleration? It is difficult to address them with the data used here because it either has insufficient time variation, or if it does, the number of observations is too low for meaningful conclusions. Therefore, more time is needed to collect the data to address similar questions for labor- and PMR reforms for a wider range of countries than the OECD.

Second, 1990 draws a meaningful division line between early and late reformers due to the fact that the bulk of the reforms were done after 1990 for most of the countries. However, imposing 1990 on all countries at the same time kills a lot of cross-country heterogeneity in reform patterns. Therefore, an interesting remaining question is how does a country's own deregulation reform pattern - not the relative reform pattern to the other countries in the distribution of reformers - influence the growth outcomes.

Finally, within each economy a different distribution of firms exists. Each of those firms reacts differently to deregulation which might be an additional factor for driving the cross-country differences in both aggregate and specific reform outcomes. Using firm-level data seems to be a promising way to go in this line of research. 


\section{Acknowledgements}

I thank Lubomír Lízal, Libor Dušek, Peter Katuščák, Evangelia Vourvachaki, Jan Švejnar, Jan Kmenta, Levent Çelik, Byeongju Jeong, Peter Ondko, Ilkin Aliyev, and Robin-Eliece Mercury for their invaluable comments on earlier versions of this work. I also thank Jiři (George) Vicek for helping me with the Czech editing. I gratefully acknowledge the financial assistance from the World Bank under the 2007 CERGE-EI/World Bank Student Grants in initiating this research. This research was partly supported by a research center grant No. LC542 of the Ministry of Education of the Czech Republic implemented at CERGE-EI. All errors are mine. 


\section{References}

Acemoglu, D., Aghion, A., \& Zilibotti, F. (2006). Distance to frontier, selection, and economic growth. Journal of the European Economic Association, 4(1), $37-74$.

Acharya, V., Baghai-Wadji, R., \& Subramanian, K. (2009). Labor laws and innovation. CEPR Discussion paper No. 7171, Feb., Retrieved June 3, 2009 from www.cepr.org/pubs/dps/DP7171.asp

Aghion, P., Alesina, A., \& Trebbi, F. (2007). Democracy, technology and growth. NBER Working Paper No. 13180. Retrieved Sept. 10, 2008 from http://www.nber.org/papers/w13180

Alesina, A., Ardagna, S., Nicoletti, G., \& Schiantarelli, F. (2005). Regulation and investment. Journal of the European Economic Association, 3(4), 791825 .

Alexeev, M., \& Conrad, R. (2009a). The elusive curse of oil. The Review of Economics and Statistics, 91(3), 586-598.

Alexeev, M., \& Conrad, R. (2009b). The natural resource curse and economic transition. CAEPR Working Paper No. 018-2009, Sept. Retrieved 15 Sept. 2009 from http://ssrn.com/abstract $=1347703$

Aliyev, I. (2009). Understanding the resource impact using matching. Mimeo, CERGE-EI. Retrieved June 14, 2009 from https://www.cerge-ei.cz/internal/study/instructions/workshops/dissertation/pdf09.asp

Autor, D., Kerr, W., \& Kugler, A. (2007). Does employment protection reduce productivity? Evidence from US states. The Economic Journal, 117, F189F217. 
Babetskii, I., \& Campos, N. (2007). Does reform work? An econometric examination of the reform-growth puzzle. CERGE-EI Working Paper No.322. Retrieved 27 April, 2007 from http://www.cerge-ei.cz/pdf/wp/Wp322.pdf

Baily, M., Gordon, R., Solow, \& R. (1981). Productivity and the services of capital and labor. Brookings Papers on Economic Activity, (1), 1-65.

Barseghyan, L. (2008). Entry costs and cross-country differences in productivity and output. Journal of Economic Growth, 13, 145-167.

Bassanini, A., Nunziata, L., \& Venn D. (2009). Job protection legislation and productivity growth in OECD countries. Economic Policy, 24(58), 349-402.

Beck, T., \& Laeven, L. (2006). Institution building and growth in transition economies. Journal of Economic Growth, 11, 157-186.

Bekaert, G., Harvey, C., \& Lundblad, C. (2005). Does financial liberalization spur growth? Journal of Financial Economics, 77(1), 3-55.

Boeri, T., \& Garibaldi, P. (2007). Two tier reforms of employment protection: a honeymoon effect? The Economic Journal, 117, F357-F385.

Botero, J., Djankov, S., La Porta, R., Lopez-de-Silanes, F., \& Shleifer, A. (2004). The regulation of labor. The Quarterly Journal of Economics, 119(4), 13391382.

Calomiris, C. (2009). Banking crises and the rules of the game. NBER Working Paper No. 15403, Retrieved Nov. 24, 2009 from

http://www.nber.org/papers/w15403

Cameron, C., \& Trivedi, P. (2005). Microeconometrics. Methods and applications. New York: Cambridge University Press.

Campos, N. \& Coricelli, F. (2002). Growth in transition: What we know, what we don't, and what we should, Journal of Economic Literature, XL, 793836. 
Cingano, F., Leonardi, M., Messina, J., \& Pica, G. (2009). The effect of employment protection legislation and financial market imperfections on investment: Evidence from a firm-level panel of EU countries. CSEF Working Paper Series No. 227. Retrieved 26 July, 2009 from

http://ideas.repec.org/p/sef/csefwp/227.html

Commander, S., \& Svejnar, J. (2007). Do institutions, ownership, exporting and competition explain firm performance? Evidence from 26 transition economies. IZA Discussion Paper No.2637. Retrieved 27 April, 2007 from ftp://repec.iza.org/RePEc/Discussionpaper/dp2637.pdf

Deakin, S., \& Sarkar, P. (2008). Assessing the long-run economic impact of labour law systems: A theoretical reappraisal and analysis of new time series data. CLPE Research Paper No. 30/2008. Retrieved July 7, 2009 from http://ssrn.com/abstract $=1278006$

Demirguc-Kunt, A., Laeven, L., \& Levine, R. (2004). Regulations, market structure, institutions, and the cost of financial intermediation. Journal of Money, Credit and Banking, 36(3), 593-622.

Demirguc-Kunt, A., \& Levine, R. (2008). Finance, financial sector policies, and long-run growth. World Bank Policy Research Working Paper No. 4469, Retrieved June 18, 2009 from http://ssrn.com/paper=1081783

Diamond, D., \& Rajan, R. (2009). The credit crisis: Conjectures about causes and remedies. American Economic Review: Papers 8 Proceedings 2009, 99(2), 606-610, Retrieved June 24, 2009 from

http://www.aeaweb.org/articles.php?doi=10.1257/aer.99.2.606

Djankov, S., La Porta, R., Lopez-de-Silanes, F., \& Shleifer, A. (2002). The regulation of entry. Quarterly Journal of Economics, 117(1), 1-37.

Djankov, S. (2009). The regulation of entry: A survey. CEPR Discussion Paper No. 7080. Retrieved Sept. 20, 2009 from www.cepr.org/pubs/dps/DP7080.asp 
Estache, A., \& Wren-Lewis, L. (2009). Toward a theory of regulation for developing countries: Following Jean-Jacques Laffont's lead. Journal of Economic Literature, 47(3), 729-770.

Estevadeordal, A., \& Taylor, A. M. (2008). Is the Washington consensus dead? Growth, openness, and the Great Liberalization. NBER Working Paper No. 14264. Retrieved Sept. 5, 2008 from http://www.nber.org/papers/w14264

Fortin, N., \& Lemieux, T. (1997). Institutional changes and rising wage inequality: Is there a linkage? The Journal of Economic Perspectives, 11(2), 75-96.

Freeman, R. B. (2007). Labor market institutions around the world. NBER Working Paper No. 13242, Retrieved July 3, 2009 from

http://www.nber.org/papers/w13242

Freeman, R. B. (2009). Labor regulations, unions, and social protection in developing countries: market distortions or efficient institutions. NBER Working Paper No. 14789, Retrieved July 3, 2009 from

http://www.nber.org/papers/w14789

Gorton, G. (2008). The panic of 2007. NBER Working Paper No. 14358, Retrieved June 18, 2009 from http://www.nber.org/papers/w14358

Gwartney, J., \& Lawson, R. (2009). Economic Freedom of the World: 2009 Annual Report. Vancouver: The Fraser Institute. Retrieved February 8, 2010 from http://www.freetheworld.com/release.html

Hanousek, J., Hajkova, D., \& Filer, R. (2008). A rise by any other name? Sensitivity of growth regressions to data source. Journal of Macroeconomics, 30, 1188-1206.

Hausmann, R., Pritchett, L., \& Rodrik, D. (2005). Growth accelerations. Journal of Economic Growth, 10, 303-329. 
Healey, N. (1990, August 4). Thatcher miracle in perspective. Economic and Political Weekly, 25(31), 1703-1704.

Heston A., Summers R., \& Aten B. (2009). Penn World Table Version 6.3, Center for International Comparisons of Production, Income and Prices at the University of Pennsylvania, August 2009.

Hoshi, T., \& Kashyap, A. (1999). The Japanese banking crisis: Where did it come from and how will it end? NBER Macroeconomics Annual, 14, 129-201.

Jayaratne, J., \& Strahan, P. (1996). The finance-growth nexus: Evidence from bank branch deregulation. The Quarterly Journal of Economics, 111(3), 639-670.

Johnson, S., Larson, W., Papageorgiou, C. \& Subramanian, A. (2009). Is newer better? Penn World Table revisions and their impact on growth estimates. NBER Working Paper Series No. 15455, Oct., Retrieved Feb. 12, 2010 from http://www.nber.org/papers/w15455

Kaufmann, D., Kraay A., \& Mastruzzi, M. (2009). Governance matters VIII: Aggregate and individual governance indicators, 1996-2008. The World Bank Policy Research Working Paper No. 4978. Retrieved June 29, 2009 from http://ssrn.com/abstract $=1424591$

Lazear, E. (1990). Job security provisions and employment. Quarterly Journal of Economics, 105(3), 699-726.

Leonardi, M., \& Pica, G. (2007). Employment protection legislation and wages. IZA Discussion Paper No. 2680, March, Retrieved March 12, 2010 from http://ftp.iza.org/dp2680.pdf

Levine, R. (1998). The legal environment, banks, and long-run economic growth. Journal of Money, Credit and Banking, 30(3), Part 2: Comparative Financial Systems, 596-613. 
Levine, R. (2005a). Finance and growth: Theory and evidence. Handbook of Economic Growth. 1A, 865-934.

Levine, R. (2005b). Law, endowments and property rights. The Journal of Economic Perspectives, 19(3), 61-88.

Levine, R. (2010). An autopsy of the U.S. financial system. NBER Working Paper Series No. 15956, Apr., Retrieved May 3, 2010 from http://www.nber.org/papers/w15956

MacLeod, W.B., \& Nakavachara, V. (2007). Can wrongful discharge law enhance employment? The Economic Journal, Vol. 117, F218-F278.

Matthews, K., Minford, P., Nickell, S., \& Helpman, E. (1987). Mrs Thatcher's economic policies 1979-1987. Economic Policy, 2(5), 59-101.

Morgan, I. (2004). Jimmy Carter, Bill Clinton, and the new democratic economics. The Historical Journal, 47(4), 1015-1039.

Nordhaus, W., Houthakker, H., \& Sachs, J. (1980). Oil and economic performance in industrial countries. Brookings Papers on Economic Activity, 11(1980-2), 341-399.

Peltzman, S. (1976). Toward a more general theory of regulation. Journal of Law and Economics, 19(2), Conference on the Economics of Politics and Regulation, 211-240.

Pera, A. (1988). Deregulation and privatization in an economy-wide context. OECD Economic Studies No. 12, Spring 1989, Retrieved Sept. 29, 2009 from http://www.oecd.org/dataoecd/18/43/35381774.pdf

Posner, R. (1975). The social costs of monopoly and regulation. The Journal of Political Economy, 83(4), 807-828.

Rodrik, D. (2008). Second-best institutions. NBER Working Paper No. 14050. Retrieved Sept. 27, 2008 from http://www.nber.org/papers/w14050 
Rosenbloom, J., \& Sundstrom, W. (2009). Labor-market regimes in US economic history. NBER Working Paper No. 15055. Retrieved July. 18, 2009 from http://www.nber.org/papers/w15055

Sachs, J. (1982). Stabilization policies in the world economy. The American Economic Review, 72(2), Papers and Proceedings of the Ninety-Fourth Annual Meeting of the American Economic Association, 56-61.

Satyanath, S., \& Berger, D. (2007). Capital controls, political institutions, and economic growth: A panel and cross country analysis, Quarterly Journal of Political Science, 2(4), 307-324.

Scarpetta, S., Hemmings, P., Tressel, T., \& Woo, J. (2002). The role of policy and institutions for productivity and firm dynamics: Evidence from micro and industry data. OECD Economics Department Working Paper No. 329, April, Retrieved June 24, 2007 from www.oecd.org/eco

Schiantarelli F. (2008). Product market regulation and macroeconomic performance: A review of cross-country evidence. Boston College Working Paper No.623. Retrieved 11 January, 2010 from http://fmwww.bc.edu/EC$\mathrm{P} / \mathrm{WP} 623 . p d f$

Scheve, K., \& Stasavage, D. (2009). Institutions, partisanship, and inequality in the long run. World Politics, 61(2), 215-253. Retrieved July 4, 2009, from Academic Research Library. (Document ID: 1701517961).

Skinner, C.W. (1995). Measuring dependence on foreign oil. Energy Information Administration/Monthly Energy Review, August, i-iii. Retrieved 22 Feb., 2009 from http://tonto.eia.doe.gov/ftproot/features/skinner1.pdf

Stigler, J. (1971). The theory of economic regulation. The Bell Journal of Economics and Management Science, 2(1), 3-21. 
Stiroh, K., \& Strahan, P. (2003). Competitive dynamics of deregulation: Evidence from U.S. banking. Journal of Money, Credit and Banking, 35(5), $801-828$.

Tymoigne, E. (2009). Securitization, deregulation, economic stability, and financial crisis, part II. The Levy Economics Institute Working Paper No. 573.2, Aug., Retrieved Sept. 4, 2009 from http://ssrn.com/abstract=1458413

Wiel, K. (2008). Better protected, better paid: Evidence on how employment protection affects wages. IZA Discussion Paper No. 3352, Feb., Retrieved Jan. 20, 2010 from ftp://repec.iza.org/RePEc/Discussionpaper/dp3352.pdf

Winston, C. (1993). Economic deregulation: Days of reckoning for microeconomists. Journal of Economic Literature, 31(3), 1263-1289.

Winston, C. (1998). U.S. industry adjustment to economic deregulation. Journal of Economic Perspectives, 12(3), 89-110.

Wölfl, A., Wanner, I., Kozluk, T., \& Nicoletti, G. (2009). Ten years of product market reforms in OECD countries - Insights from a revised PMR indicator. OECD Economics Department Working Papers No. 695, Apr., Retrieved Sept. 13, 2009 from http://www.oecd.org/dataoecd/29/41/42779045.pdf 


\section{Tables}

Table 1: Deregulation and the increase in the Average Log(GDP/c.): 1975-2004

\begin{tabular}{|c|c|c|c|c|c|c|c|c|}
\hline & \multicolumn{8}{|c|}{ Difference in Average $\log ($ GDP/c. $): 1975-1990$ Vs. $1990-2004$} \\
\hline & \multicolumn{4}{|c|}{ Using median criterion } & \multicolumn{4}{|c|}{ Using mean criterion } \\
\hline & $\begin{array}{l}\text { OLS } \\
(1)\end{array}$ & $\begin{array}{c}\text { 2SLS } \\
(2)\end{array}$ & $\begin{array}{c}\text { OLS } \\
(3)\end{array}$ & $\begin{array}{c}\text { 2SLS } \\
(4)\end{array}$ & $\begin{array}{c}\text { OLS } \\
(5)\end{array}$ & $\begin{array}{c}\text { 2SLS } \\
(6)\end{array}$ & $\begin{array}{c}\text { OLS } \\
(7)\end{array}$ & $\begin{array}{c}\text { 2SLS } \\
(8)\end{array}$ \\
\hline ER & $\begin{array}{c}.298^{* * *} \\
(.097)\end{array}$ & $\begin{array}{c}.539^{* * *} \\
(.166)\end{array}$ & - & - & $\begin{array}{c}.283^{* * *} \\
(.103)\end{array}$ & $\begin{array}{c}.503^{* * *} \\
(.162)\end{array}$ & - & - \\
\hline LR & $\begin{array}{l}.157 \\
(.109)\end{array}$ & $\begin{array}{c}.285 \\
(.219)\end{array}$ & - & - & $\begin{array}{l}.009 \\
(.137)\end{array}$ & $\begin{array}{l}.007 \\
(.277)\end{array}$ & - & - \\
\hline $\mathrm{MR}$ & $\begin{array}{l}.324^{* *} \\
(.128)\end{array}$ & $\begin{array}{c}.574^{* * *} \\
(.202)\end{array}$ & - & - & $\begin{array}{l}.292^{* *} \\
(.118)\end{array}$ & $\begin{array}{c}.480^{* * *} \\
(.184)\end{array}$ & - & \\
\hline CM-ER & - & - & $\begin{array}{l}.077 \\
(.091)\end{array}$ & $\begin{array}{c}.243 \\
(.173)\end{array}$ & - & - & $\begin{array}{c}.109 \\
(.078)\end{array}$ & $\begin{array}{c}.216 \\
(.146)\end{array}$ \\
\hline CM-LR & - & - & $\begin{array}{c}-.223^{* *} \\
(.102)\end{array}$ & $\begin{array}{c}-.353^{* * *} \\
(.121)\end{array}$ & - & - & $\begin{array}{l}-.151 \\
(.094)\end{array}$ & $\begin{array}{c}-.321^{* * * *} \\
(.114)\end{array}$ \\
\hline CM-MR & - & - & $\begin{array}{l}-.079 \\
(.093)\end{array}$ & $\begin{array}{c}.001 \\
(.186)\end{array}$ & - & - & $\begin{array}{l}-.072 \\
(.105)\end{array}$ & $\begin{array}{l}-.128 \\
(.122)\end{array}$ \\
\hline FT-ER & $\begin{array}{l}-.063 \\
(.110)\end{array}$ & $\begin{array}{r}-.417^{*} \\
(.226)\end{array}$ & $\begin{array}{l}.063 \\
(.090)\end{array}$ & $\begin{array}{l}-.071 \\
(.164)\end{array}$ & $\begin{array}{l}-.051 \\
(.095)\end{array}$ & $\begin{array}{l}-.350 \\
(.213)\end{array}$ & $\begin{array}{l}.085 \\
(.088)\end{array}$ & $\begin{array}{c}.037 \\
(.155)\end{array}$ \\
\hline FT-LR & $\begin{array}{l}-.089 \\
(.094)\end{array}$ & $\begin{array}{c}-.337^{*} \\
(.176)\end{array}$ & $\begin{array}{c}.032 \\
(.084)\end{array}$ & $\begin{array}{c}.182 \\
(.147)\end{array}$ & $\begin{array}{l}-.065 \\
(.107)\end{array}$ & $\begin{array}{c}-.339^{* *} \\
(.164)\end{array}$ & $\begin{array}{c}.081 \\
(.083)\end{array}$ & $\begin{array}{l}.294^{*} \\
(.155)\end{array}$ \\
\hline FT-MR & $\begin{array}{l}-.055 \\
(.093)\end{array}$ & $\begin{array}{l}-.216 \\
(.163)\end{array}$ & $\begin{array}{l}.098 \\
(.082)\end{array}$ & $\begin{array}{l}.044 \\
(.125)\end{array}$ & $\begin{array}{l}-.055 \\
(.110)\end{array}$ & $\begin{array}{l}-.111 \\
(.165)\end{array}$ & $\begin{array}{l}.108 \\
(.089)\end{array}$ & $\begin{array}{l}.099 \\
(.132)\end{array}$ \\
\hline $\begin{array}{l}\log \text { (RGDP- } \\
75)\end{array}$ & $\begin{array}{c}.041 \\
(.036)\end{array}$ & $\begin{array}{l}.031 \\
(.040)\end{array}$ & $\begin{array}{l}.039 \\
(.036)\end{array}$ & $\begin{array}{c}.061 \\
(.043)\end{array}$ & $\begin{array}{l}.019 \\
(.041)\end{array}$ & $\begin{array}{l}-.006 \\
(.044)\end{array}$ & $\begin{array}{l}.046 \\
(.037)\end{array}$ & $\begin{array}{l}.063 \\
(.040)\end{array}$ \\
\hline Const. & $\begin{array}{l}-.259 \\
(.331)\end{array}$ & $\begin{array}{l}-.127 \\
(.369)\end{array}$ & $\begin{array}{l}-.146 \\
(.363)\end{array}$ & $\begin{array}{l}-.372 \\
(.463)\end{array}$ & $\begin{array}{l}-.059 \\
(.377)\end{array}$ & $\begin{array}{c}.207 \\
(.416)\end{array}$ & $\begin{array}{l}-.262 \\
(.360)\end{array}$ & $\begin{array}{l}-.448 \\
(.413)\end{array}$ \\
\hline$R^{2}$ & 0.233 & 0.373 & 0.185 & 0.324 & 0.235 & 0.382 & 0.148 & 0.307 \\
\hline J-Test & - & 0.289 & - & 0.232 & - & 0.593 & - & 0.159 \\
\hline $\mathrm{N}$ & 68 & 67 & 92 & 91 & 68 & 67 & 92 & 91 \\
\hline
\end{tabular}

Notes: The estimated OLS equation is $\Delta$ Avg. $\log (G D P)_{i t}=\beta_{1}+\beta_{2} \mathrm{ER}_{i t}+\beta_{3} \mathrm{LR}_{i t}+$ $\beta_{4} \mathrm{MR}_{i t}+\beta_{5} X_{i t}+\Delta \varepsilon_{i t}$, where $\Delta$ Avg. $\log (G D P)_{i t}$ is the difference in the average log-levels of per capita GDP. The variables ER, LR and MR are the Early reformers, Late reformers, and Marathon reformers, respectively as defined in the text. The variables CM-ER, CM-LR and CM-MR are the early-, late-, and marathon reformers in the credit market regulation as defined in the text. The variables FT-ER, FT-LR and FT-MR are the early-, late-, and marathon reformers in the freedom to trade internationally as defined in the text. Log(RGDP-'75) indicates the real GDP per capita in 1975 or the first non-missing value thereof. Robust standard errors are presented in parentheses. J-Test is the P-value on the Hansen over-identification restriction J-test. 
Table 2: Deregulation and Compound Economic Growth: 1975-2004

\begin{tabular}{|c|c|c|c|c|c|c|c|c|}
\hline & \multicolumn{4}{|c|}{$\begin{array}{l}\text { Difference in Compound GDP /c. } \\
\text { Using median criterion }\end{array}$} & \multicolumn{4}{|c|}{ 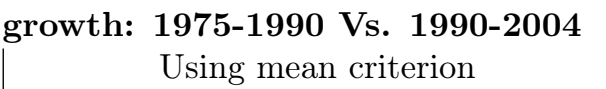 } \\
\hline & $\begin{array}{l}\text { OLS } \\
(1)\end{array}$ & $\begin{array}{c}\text { 2SLS } \\
(2)\end{array}$ & $\begin{array}{c}\text { OLS } \\
(3)\end{array}$ & $\begin{array}{c}\text { 2SLS } \\
(4)\end{array}$ & $\begin{array}{c}\text { OLS } \\
(5)\end{array}$ & $\begin{array}{c}\text { 2SLS } \\
(6)\end{array}$ & $\begin{array}{c}\text { OLS } \\
(7)\end{array}$ & $\begin{array}{c}\text { 2SLS } \\
(8)\end{array}$ \\
\hline ER & $\begin{array}{l}-.975 \\
(.699)\end{array}$ & $\begin{array}{c}-.805 \\
(1.370)\end{array}$ & - & - & $\begin{array}{l}-.551 \\
(.812)\end{array}$ & $\begin{array}{c}-.437 \\
(1.21)\end{array}$ & - & - \\
\hline LR & $\begin{array}{l}-.021 \\
(1.11)\end{array}$ & $\begin{array}{c}1.879 \\
(1.737)\end{array}$ & - & - & $\begin{array}{c}2.043 \\
(1.412)\end{array}$ & $\begin{array}{c}5.064^{* *} \\
(1.981)\end{array}$ & - & - \\
\hline MR & $\begin{array}{l}-.219 \\
(.847)\end{array}$ & $\begin{array}{l}-1.148 \\
(1.935)\end{array}$ & - & - & $\begin{array}{c}-.202 \\
(1.016)\end{array}$ & $\begin{array}{c}-.590 \\
(1.637)\end{array}$ & - & \\
\hline CM-ER & - & - & $\begin{array}{l}.434 \\
(.587)\end{array}$ & $\begin{array}{c}-.714 \\
(1.126)\end{array}$ & - & - & $\begin{array}{l}.627 \\
(.525)\end{array}$ & $\begin{array}{c}.005 \\
(1.163)\end{array}$ \\
\hline CM-LR & - & - & $\begin{array}{l}1.609^{*} \\
(.885)\end{array}$ & $\begin{array}{l}3.242^{* * *} \\
(.999)\end{array}$ & - & - & $\begin{array}{l}1.622^{*} \\
(.855)\end{array}$ & $\begin{array}{c}3.644^{* * *} \\
(1.004)\end{array}$ \\
\hline CM-MR & - & - & $\begin{array}{l}1.278 \\
(.790)\end{array}$ & $\begin{array}{c}.083 \\
(1.870)\end{array}$ & - & - & $\begin{array}{l}1.016 \\
(.981)\end{array}$ & $\begin{array}{c}.502 \\
(1.858)\end{array}$ \\
\hline FT-ER & $\begin{array}{l}-.365 \\
(.708)\end{array}$ & $\begin{array}{c}-.172 \\
(1.741)\end{array}$ & $\begin{array}{l}-.576 \\
(.590)\end{array}$ & $\begin{array}{c}-.527 \\
(1.285)\end{array}$ & $\begin{array}{l}-.294 \\
(.780)\end{array}$ & $\begin{array}{l}-.115 \\
(1.558)\end{array}$ & $\begin{array}{l}-.521 \\
(.609)\end{array}$ & $\begin{array}{c}-.179 \\
(1.226)\end{array}$ \\
\hline FT-LR & $\begin{array}{c}1.594 \\
(1.100)\end{array}$ & $\begin{array}{l}2.950^{*} \\
(1.637)\end{array}$ & $\begin{array}{l}1.076 \\
(.830)\end{array}$ & $\begin{array}{c}1.399 \\
(1.560)\end{array}$ & $\begin{array}{c}1.453 \\
(1.124)\end{array}$ & $\begin{array}{c}3.549^{* *} \\
(1.728)\end{array}$ & $\begin{array}{c}.992 \\
(.802)\end{array}$ & $\begin{array}{c}1.726 \\
(1.629)\end{array}$ \\
\hline FT-MR & $\begin{array}{l}1.136 \\
(.751)\end{array}$ & $\begin{array}{c}.746 \\
(1.366)\end{array}$ & $\begin{array}{c}.929 \\
(.694)\end{array}$ & $\begin{array}{c}.661 \\
(1.485)\end{array}$ & $\begin{array}{l}1.160 \\
(.858)\end{array}$ & $\begin{array}{c}-.004 \\
(1.527)\end{array}$ & $\begin{array}{c}.927 \\
(.690)\end{array}$ & $\begin{array}{c}.153 \\
(1.692)\end{array}$ \\
\hline $\begin{array}{l}\text { Log (RGDP- } \\
\text { '75) }\end{array}$ & $\begin{array}{l}.169 \\
(.264)\end{array}$ & $\begin{array}{c}.511 \\
(.339)\end{array}$ & $\begin{array}{l}.484^{*} \\
(.263)\end{array}$ & $\begin{array}{l}.568^{*} \\
(.333)\end{array}$ & $\begin{array}{l}.413 \\
(.329)\end{array}$ & $\begin{array}{l}.898^{*} \\
(.480)\end{array}$ & $\begin{array}{l}.479^{*} \\
(.271)\end{array}$ & $\begin{array}{l}.616^{*} \\
(.350)\end{array}$ \\
\hline Const. & $\begin{array}{l}-1.530 \\
(2.321)\end{array}$ & $\begin{array}{l}-4.986 \\
(3.195)\end{array}$ & $\begin{array}{c}-5.088^{* *} \\
(2.534)\end{array}$ & $\begin{array}{l}-5.603 \\
(3.731)\end{array}$ & $\begin{array}{l}-3.949 \\
(2.859)\end{array}$ & $\begin{array}{c}-8.678^{*} \\
(4.458)\end{array}$ & $\begin{array}{c}-4.876^{*} \\
(2.549)\end{array}$ & $\begin{array}{c}-6.315^{*} \\
(3.796)\end{array}$ \\
\hline$R^{2}$ & 0.127 & -0.104 & 0.150 & -0.058 & 0.168 & -0.152 & 0.122 & -0.055 \\
\hline J-Test & - & 0.469 & - & 0.547 & - & 0.459 & - & 0.432 \\
\hline $\mathrm{N}$ & 68 & 67 & 92 & 91 & 68 & 67 & 92 & 91 \\
\hline
\end{tabular}

Notes: The estimated OLS equation is $\Delta g_{i t}=\beta_{1}+\beta_{2} \mathrm{ER}_{i t}+\beta_{3} \mathrm{LR}_{i t}+\beta_{4} \mathrm{MR}_{i t}+\beta_{5} X_{i t}+$ $\Delta \varepsilon_{i t}$, where $\Delta g_{i t}$ is the difference in the compound growth rate between the two periods. The variables ER, LR and MR are the Early reformers, Late reformers, and Marathon reformers, respectively as defined in the text. The variables CM-ER, CM-LR and CM-MR are the early-, late-, and marathon reformers in the credit market regulation as defined in the text. The variables FT-ER, FT-LR and FT-MR are the early-, late-, and marathon reformers in the freedom to trade internationally as defined in the text. Log(RGDP-'75) indicates the real GDP per capita in 1975 or the first non-missing value thereof. Robust standard errors are presented in parentheses. J-Test is the P-value on the Hansen overidentification restriction J-test. 
Table 3: Classic diff-in-diff: Non-reformers Vs. Late reformers Panel A: Level effects

\begin{tabular}{|c|c|c|c|c|}
\hline & \\
\hline & $\begin{array}{c}(1) \\
\text { OLS }\end{array}$ & $\begin{array}{c}(2) \\
2 \text { SLS }\end{array}$ & $\begin{array}{c}(3) \\
\text { OLS }\end{array}$ & $\begin{array}{c}(4) \\
\text { 2SLS }\end{array}$ \\
\hline LR & $\begin{array}{l}0.198^{*} \\
(0.106)\end{array}$ & $\begin{array}{c}0.192^{* *} \\
(0.0924)\end{array}$ & - & - \\
\hline FTLR & $\begin{array}{l}-0.0996 \\
(0.115)\end{array}$ & $\begin{array}{l}-0.171^{*} \\
(0.0980)\end{array}$ & $\begin{array}{l}0.0465 \\
(0.103)\end{array}$ & $\begin{array}{l}0.0832 \\
(0.108)\end{array}$ \\
\hline $\begin{array}{l}\log (\text { RGDP- } \\
\left.{ }^{7} 75\right)\end{array}$ & $\begin{array}{c}0.109^{* *} \\
(0.0482)\end{array}$ & $\begin{array}{l}0.123^{* * *} \\
(0.0467)\end{array}$ & $\begin{array}{c}0.0311 \\
(0.0575)\end{array}$ & $\begin{array}{c}0.0543 \\
(0.0584)\end{array}$ \\
\hline CMLR & - & - & $\begin{array}{l}-0.169 \\
(0.113)\end{array}$ & $\begin{array}{l}-0.168 \\
(0.126)\end{array}$ \\
\hline Const. & $\begin{array}{l}-0.865^{*} \\
(0.455)\end{array}$ & $\begin{array}{c}-0.978^{* *} \\
(0.443)\end{array}$ & $\begin{array}{l}-0.103 \\
(0.550)\end{array}$ & $\begin{array}{l}-0.327 \\
(0.574)\end{array}$ \\
\hline \multirow{4}{*}{$\begin{array}{l}\mathrm{N} \\
R^{2}\end{array}$} & 33 & 32 & 40 & 39 \\
\hline & 0.191 & 0.199 & 0.101 & 0.149 \\
\hline & \multicolumn{4}{|c|}{ Panel B: Acceleration effects } \\
\hline & $\begin{array}{l}(1) \\
\text { OLS }\end{array}$ & $\begin{array}{c}(2) \\
2 \mathrm{SLS}\end{array}$ & $\begin{array}{l}(3) \\
\text { OLS }\end{array}$ & $\begin{array}{c}(4) \\
\text { 2SLS }\end{array}$ \\
\hline LR & $\begin{array}{l}-0.312 \\
(1.183)\end{array}$ & $\begin{array}{c}0.447 \\
(1.171)\end{array}$ & - & - \\
\hline FTLR & $\begin{array}{l}1.728 \\
(1.730)\end{array}$ & $\begin{array}{c}1.964 \\
(1.539)\end{array}$ & $\begin{array}{c}0.594 \\
(1.194)\end{array}$ & $\begin{array}{l}2.609^{* *} \\
(1.223)\end{array}$ \\
\hline $\begin{array}{l}\log (\text { RGDP- } \\
' 75)\end{array}$ & $\begin{array}{l}-0.209 \\
(0.387)\end{array}$ & $\begin{array}{l}-0.128 \\
(0.397)\end{array}$ & $\begin{array}{l}0.768^{*} \\
(0.393)\end{array}$ & $\begin{array}{l}1.031^{* *} \\
(0.436)\end{array}$ \\
\hline CMLR & - & - & $\begin{array}{l}1.999^{* *} \\
(0.970)\end{array}$ & $\begin{array}{c}3.354^{* * *} \\
(0.961)\end{array}$ \\
\hline Const. & $\begin{array}{c}1.922 \\
(3.467)\end{array}$ & $\begin{array}{c}0.868 \\
(3.528)\end{array}$ & $\begin{array}{l}-7.254^{*} \\
(3.683)\end{array}$ & $\begin{array}{c}-10.83^{* * *} \\
(4.149)\end{array}$ \\
\hline $\mathrm{N}$ & 33 & 32 & 40 & 39 \\
\hline$R^{2}$ & 0.060 & 0.041 & 0.141 & 0.001 \\
\hline
\end{tabular}

Notes: Standard errors in parentheses; Source: PWT 6.3 data; EFW index; US EIA data; ${ }^{*} p<.10,{ }^{* *} p<.05,{ }^{* * *} p<.01$. 
Table 4: Classic diff-in-diff: Early reformers Vs. Marathon reformers Panel A: Level effects

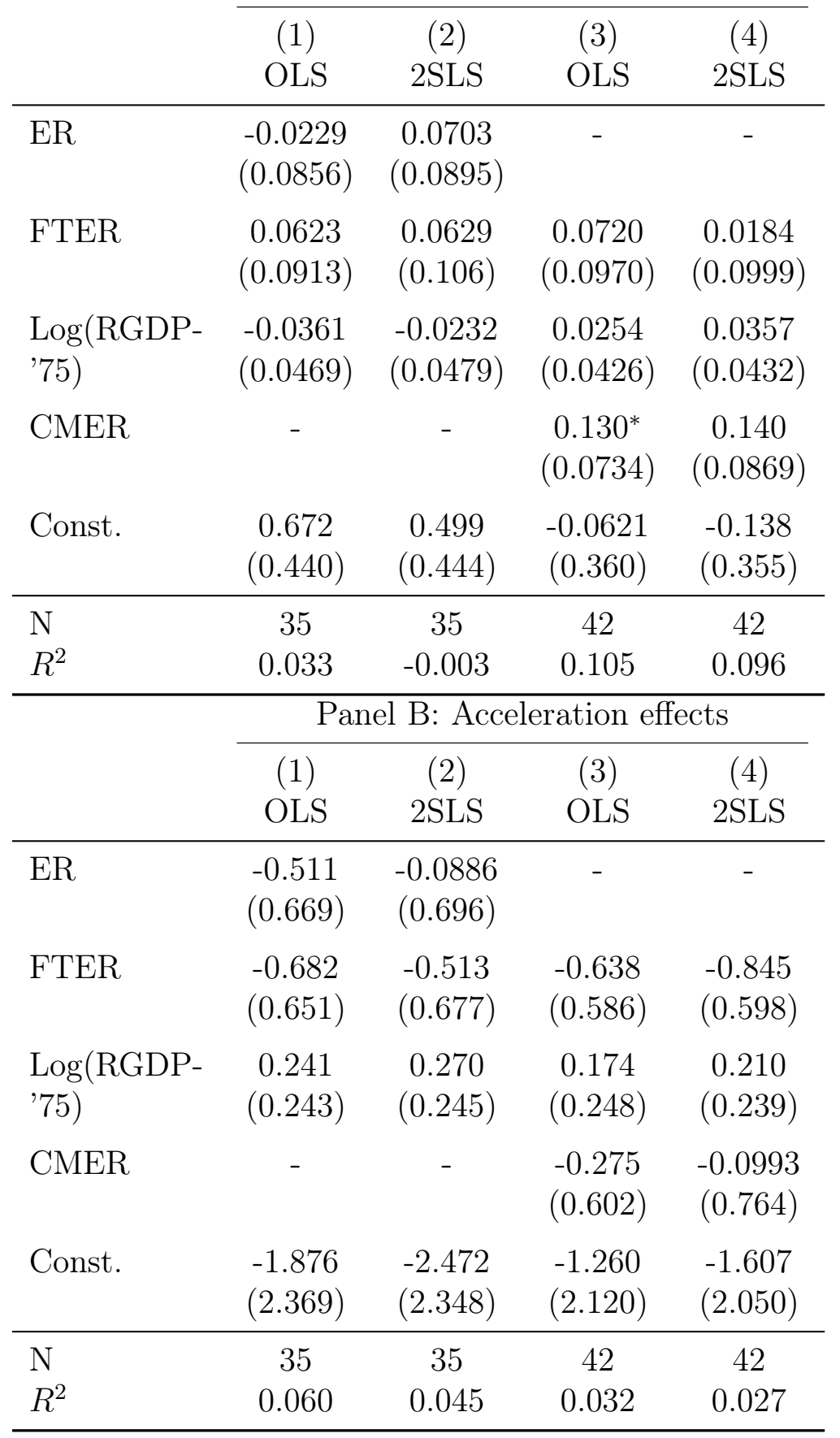

Notes: Standard errors in parentheses; Source: PWT 6.3 data; EFW index; US EIA data; ${ }^{*} p<.10,{ }^{* *} p<.05,{ }^{* * *} p<.01$. 
Table 5: Who are the reformers and the non-reformers?

\begin{tabular}{|c|c|c|}
\hline \multirow[t]{2}{*}{ Type } & \multicolumn{2}{|c|}{ Country } \\
\hline & Using the median criterion & Using the mean criterion \\
\hline Early & $\begin{array}{l}\text { Australia, Austria, Bangla- } \\
\text { desh, Belgium, Canada, } \\
\text { Germany, Greece, India, In- } \\
\text { donesia, Ireland, Italy, Japan, } \\
\text { Kenya, Malaysia, Pakistan, } \\
\text { Philippines, Rwanda, Taiwan, } \\
\text { Thailand, Turkey, United } \\
\text { Kingdom, United States }\end{array}$ & $\begin{array}{l}\text { Australia, Austria, Bangla- } \\
\text { desh, Belgium, Canada, } \\
\text { Germany, Greece, India, In- } \\
\text { donesia, Ireland, Italy, Japan, } \\
\text { Kenya, Malaysia, Pakistan, } \\
\text { Philippines, Rwanda, Spain, } \\
\text { Taiwan, Thailand, Turkey, } \\
\text { United Kingdom, United } \\
\text { States }\end{array}$ \\
\hline Late & $\begin{array}{l}\text { Bahamas, Burundi, Cyprus, } \\
\text { Finland, Ghana, Hong Kong, } \\
\text { Kuwait, Mexico, Myanmar, } \\
\text { Nigeria, Norway, Romania, } \\
\text { Syria, Tanzania, Uganda, } \\
\text { Zambia }\end{array}$ & $\begin{array}{l}\text { Bahamas, Burundi, Ghana, } \\
\text { Kuwait, Myanmar, Nigeria, } \\
\text { Tanzania, Uganda, Zambia }\end{array}$ \\
\hline Marathon & $\begin{array}{l}\text { Chile, Denmark, Fiji, Ice- } \\
\text { land, Israel, Netherlands, New } \\
\text { Zealand, Portugal, Singapore, } \\
\text { South Korea, Sweden, Switzer- } \\
\text { land, Tunisia }\end{array}$ & $\begin{array}{l}\text { Chile, Denmark, Fiji, Fin- } \\
\text { land, Hong Kong, Iceland, } \\
\text { Israel, Mexico, Netherlands, } \\
\text { New Zealand, Norway, Por- } \\
\text { tugal, Romania, Singapore, } \\
\text { South Korea, Sweden, Switzer- } \\
\text { land, Syria, Tunisia }\end{array}$ \\
\hline Non-reformer & $\begin{array}{l}\text { Argentina, Bahrain, Barba- } \\
\text { dos, Brazil, Democratic Re- } \\
\text { public of Congo, Costa Rica, } \\
\text { France, Guatemala, Jordan, } \\
\text { Luxembourg, Malawi, Mali, } \\
\text { Mauritius, Niger, Panama, } \\
\text { Sierra Leone, South Africa, } \\
\text { Spain, Trinidad and Tobago, } \\
\text { Venezuela }\end{array}$ & $\begin{array}{l}\text { Argentina, Bahrain, Barbados, } \\
\text { Brazil, Democratic Repub- } \\
\text { lic of Congo, Costa Rica, } \\
\text { Cyprus, France, Guatemala, } \\
\text { Jordan, Luxembourg, Malawi, } \\
\text { Mali, Mauritius, Niger, } \\
\text { Panama, Sierra Leone, South } \\
\text { Africa, Trinidad and Tobag, } \\
\text { Venezuela }\end{array}$ \\
\hline
\end{tabular}

Notes: The economies above are classified by applying the above-median (abovemean) discrimination criterion based only on their overall deregulation performance. 


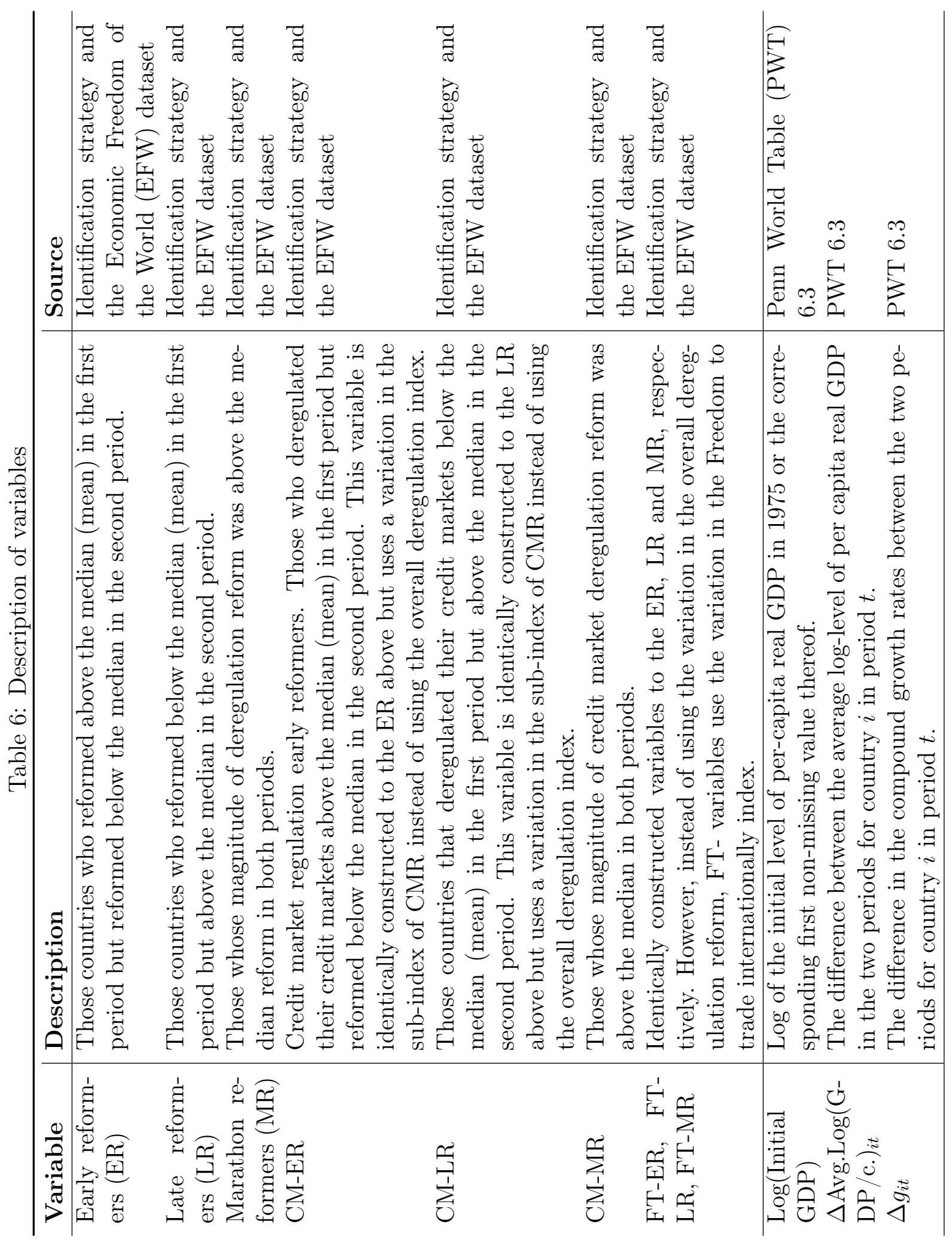




\section{Working Paper Series}

ISSN 1211-3298

Registration No. (Ministry of Culture): E 19443

Individual researchers, as well as the on-line and printed versions of the CERGE-EI Working Papers (including their dissemination) were supported from the European Structural Fund (within the Operational Programme Prague Adaptability), the budget of the City of Prague, the Czech Republic's state budget and the following institutional grants:

- Center of Advanced Political Economy Research [Centrum pro pokročilá politickoekonomická studia], No. LC542, (2005-2010);

- Economic Aspects of EU and EMU Entry [Ekonomické aspekty vstupu do Evropské unie a Evropské měnové unie], No. AVOZ70850503, (2005-2010);

- Economic Impact of European Integration on the Czech Republic [Ekonomické dopady evropské integrace na ČR], No. MSM0021620846, (2005-2011);

Specific research support and/or other grants the researchers/publications benefited from are acknowledged at the beginning of the Paper.

(c) Petar Stankov, 2010

All rights reserved. No part of this publication may be reproduced, stored in a retrieval system or transmitted in any form or by any means, electronic, mechanical or photocopying, recording, or otherwise without the prior permission of the publisher.

Published by

Charles University in Prague, Center for Economic Research and Graduate Education (CERGE) and

Economics Institute ASCR, v. v. i. (EI)

CERGE-El, Politických vězňů 7, 11121 Prague 1, tel.: +420 224005 153, Czech Republic.

Printed by CERGE-EI, Prague

Subscription: CERGE-EI homepage: http://www.cerge-ei.cz

Phone: + 420224005153

Email: office@cerge-ei.cz

Web: http://www.cerge-ei.cz

Editor: Michal Kejak

Editorial board: Jan Kmenta, Randall Filer, Petr Zemčík

The paper is available online at http://www.cerge-ei.cz/publications/working_papers/.

ISBN 978-80-7343-223-2 (Univerzita Karlova. Centrum pro ekonomický výzkum a doktorské studium)

ISBN 978-80-7344-213-2 (Národohospodářský ústav AV ČR, v. v. i.) 
CERGE-EI

P.O.BOX 882

Politických vězňů 7

11121 Praha 1

Czech Republic http://www.cerge-ei.cz 